\title{
Cells of the rectum of Bombyx mori affected by experimental inoculation with Alphabaculovirus
}

\author{
S.A. Vessaro-Silva, R.M.C. Brancalhão, M.P.D. Baggio and L.F.C. Ribeiro \\ Laboratório de Biologia Celular, Universidade Estadual do Oeste do Paraná, \\ Cascavel, PR, Brasil \\ Corresponding author: L.F.C. Ribeiro \\ E-mail: lucineia.cr@gmail.com
}

Genet. Mol. Res. 13 (3): 6885-6891 (2014)

Received July 11, 2013

Accepted January 13, 2014

Published August 29, 2014

DOI http://dx.doi.org/10.4238/2014.August.29.10

\begin{abstract}
Bombyx mori is an insect whose cocoon is used in the sericulture industry, which is an important activity in parts of southern Brazil. When parasitized by Bombyx mori nucleopolyhedrovirus (BmNPV) of the genus Alphabaculovirus (alphaBV), it develops nuclear polyhedrosis disease. In Brazil, an alphaBV was isolated from larvae of $B$. mori and various target tissues were identified. However, how this geographic viral isolate affects the rectum of silk moths was unknown. The rectum, a component of the cryptonephric system, acts to absorb water and mineral salts, and its importance for the metabolic balance of insects provoked interest in analyzing how it is affected by BmMNPV infection. Fifth instar B. mori larvae were inoculated with a viral suspension, and from the second to the ninth day post-inoculation, segments of the rectum (anterior and anal canal) were examined using light microscopy. The cryptonephric epithelial cells in the anterior region revealed no evidence of infection. However, from the fifth day post-inoculation, cells of the anal canal showed cytopathologies characteristic of alphaBV. Infection of the anal canal and other surrounding tissues led to tissue disorganization, with accumulation
\end{abstract}


of polyhedra in the perinephric space and compartmentalization of the cryptonephric system, promoting changes in the fecal pellets, signalling physiological changes. These observations contribute to our understanding of the infectious cycle of BmMNPV in B. mori.

Key words: Cytopathology; Lepidoptera; Viral polyhedra; Baculovirus; Cryptonephric system

\section{INTRODUCTION}

Baculoviridae is a viral family that is interesting due to its ability to regulate insect pest populations and it can also be used as gene vectors for medical research and biotechnology. However, Bombyx mori nucleopolyhedrovirus (BmNPV), genus Alphabaculovirus (AlphaBV), affects Bombyx mori, an insect of economic interest causing the disease known as nuclear polyhedrosis, which leads to considerable losses in sericulture production (Brancalhão, 2002; Ikuno et al., 2004; Rohrmann, 2011).

Nucleopolyhedroviruses have double-stranded DNA that is associated with proteins, producing enveloped nucleocapsids, or virions, which can be classified into simple (SNPVs) when they have one nucleocapsid per envelope, and multiple (MNPVs) when they have more than one nucleocapsid per envelope (Hu et al., 1999; Rohrmann, 2011). In Brazil, in the state of Paraná, a geographic isolate of BmNPV with multiple characteristics, BmMNPV, was obtained from larvae of B. mori (Pereira et al., 2008). According to Adams and McClintock (1991), Hong et al. (2000) and Fan et al. (2007), multiple nucleocapsids are considered to be more virulent, with evidence of variability among geographic isolates of the same species (Liang et al., 2013).

The infectious cycle of baculovirus shows two distinct phenotypes: the polyhedronderived virus (PDV) and bud viruses (BV). PDV is characterized by having nucleocapsids surrounded by a crystalline protein matrix, forming the polyhedron, which is responsible for the primary infection in the midgut of the larvae. BV is produced after the primary infection in host cells, consisting of a single enveloped nucleocapsid and is responsible for systemic or secondary infection in the body of the insect (Jehle et al., 2006; Rohrmann, 2011).

BmMNPV is polyorganothropic, and in the larvae of B. mori several targets have been identified such as the fatty body (Brancalhão et al., 2002), integument (Brancalhão and Ribeiro, 2003), central nervous system (Torquato et al., 2006a), testis (Pereira et al., 2008), cardia (Ribeiro et al., 2009a), and the middle and posterior regions of the silk gland (Brancalhão et al., 2009). However, we do not know the behavior of the rectum with regard to this geographic isolate of the virus. The region of the hindgut of the larvae forms part of the cryptonephric system and acts in the water/electrolyte balance of the insect. It is also responsible for the formation and elimination of fecal pellets (Reinecke et al., 1973; Chapman, 1998; Azuma et al., 2012).

In morphological terms, the rectum of some Lepidoptera is subdivided into anterior and posterior regions, which extend to the integument, forming the anal canal. In the anterior region the cryptonephric rectal epithelium is simple and is covered by an intima that is detached, while in the anal canal the intima adheres to the simple epithelium (Henson, 1937; Srivastava, 1959; Ramsay, 1976; MacGown and Sikorowski, 1982; Azuma et al., 2012).

Given the importance of this organ for the metabolism of the insect, which is directly reflected in the production of silk, this study analyzed the behavior of the rectum in relation to 
the geographic isolate of Paraná, Brazil, of BmMNPV, to contribute to the study of the establishment of the infectious cycle of this pathogen in larvae of B. mori.

\section{MATERIAL AND METHODS}

\section{Obtaining the insects}

Hybrid larvae of B. mori (Lepidoptera, Bombycidae), in the third instar of development, obtained from a sericulture company in Paraná State, Brazil, were raised in polyethylene boxes until the end of the experiment and kept in a breeding room in conditions similar to those found in the field. The larvae were fed three times a day, with fresh mulberry leaves (Morus sp.).

\section{Geographic isolate of BmMNPV and inoculation}

The viral inoculum of Bombyx mori multiple nucleopolyhedrovirus, BmMNPV, geographic isolate (GenBank accession No. EU251694.1) was obtained from larvae of previously infected B. mori (Brancalhão, 2002). The viral suspension was quantified by counting the number of viral polyhedra in a Neubauer chamber at a concentration of $2.4 \times 10^{7} \mathrm{POBs} / \mathrm{mL}$ ( $\mathrm{POBs}=$ polyhedral occlusion bodies $)$.

Virus suspension $(10 \mu \mathrm{L})$ was placed on mulberry leaf discs $\left(2 \mathrm{~cm}^{3}\right.$ in diameter $)$ and supplied in the feed of 50 larvae on the first day of the fifth instar. Likewise, leaf discs containing purified water were offered to larvae in the control group. At the end of feeding on the leaf discs, the larvae (control and inoculated) were transferred to the boxes and were fed mulberry leaves without the suspension.

\section{Light microscopy}

In the microscopic preparation, 5 larvae from the inoculated group and 5 from the control group, from the 2nd to the 9th day post-inoculation (dpi), with 24-h intervals, were randomly selected, anesthetized with ether and dissected. Segments of the hindgut, containing the rectum, were placed in individual flasks containing Dubosq Brazil fixative (Beçak and Paullete, 1976) for $24 \mathrm{~h}$ at $4^{\circ} \mathrm{C}$.

Subsequently, the intestinal segments were subjected to routine histological procedures and embedded in paraffin (Junqueira and Junqueira, 1983). The blocks were sectioned in a microtome at a thickness of $7 \mu \mathrm{m}$. The slides obtained were stained by the Azan cytochemical technique, modified for viral occlusion bodies (Hamm, 1966). This was followed by light microscopy analysis and the fields of interest were photomicrographed. Material from the control group followed the same procedure as the inoculated group.

\section{RESULTS AND DISCUSSION}

The rectum of larvae of $B$. mori presented differential behavior in its regions by experimental inoculation with the geographic isolate BmMNPV. Thus, the infection of the epithelial cells of the anal canal was verified from the fifth dpi (Figure 1A, B, and C), while in 
the anterior region, the cells of the cryptonephric rectal epithelium showed no evidence of infection during the periods analyzed (Figures 1 A, 2A, B, and C). It was possible to follow the infectious cycle of BmMNPV in the nuclei of the infected cells of the anal canal. Initially, the formation of the virogenic stroma occurred (Figure 1B), which according to Adams and McClintock (1991), is the site of the synthesis of viral DNA and its enveloping, forming virions. Rorhmann (2011) notes that the viral envelope is formed from microvesicles derived from the inner nuclear membrane and subsequently virions aggregate polyhedrin protein, which crystallizes around them, forming polyhedra. At this stage of the infectious cycle, the nuclei appeared hypertrophic, which was also observed in cells of the anal canal (Figure 1B).

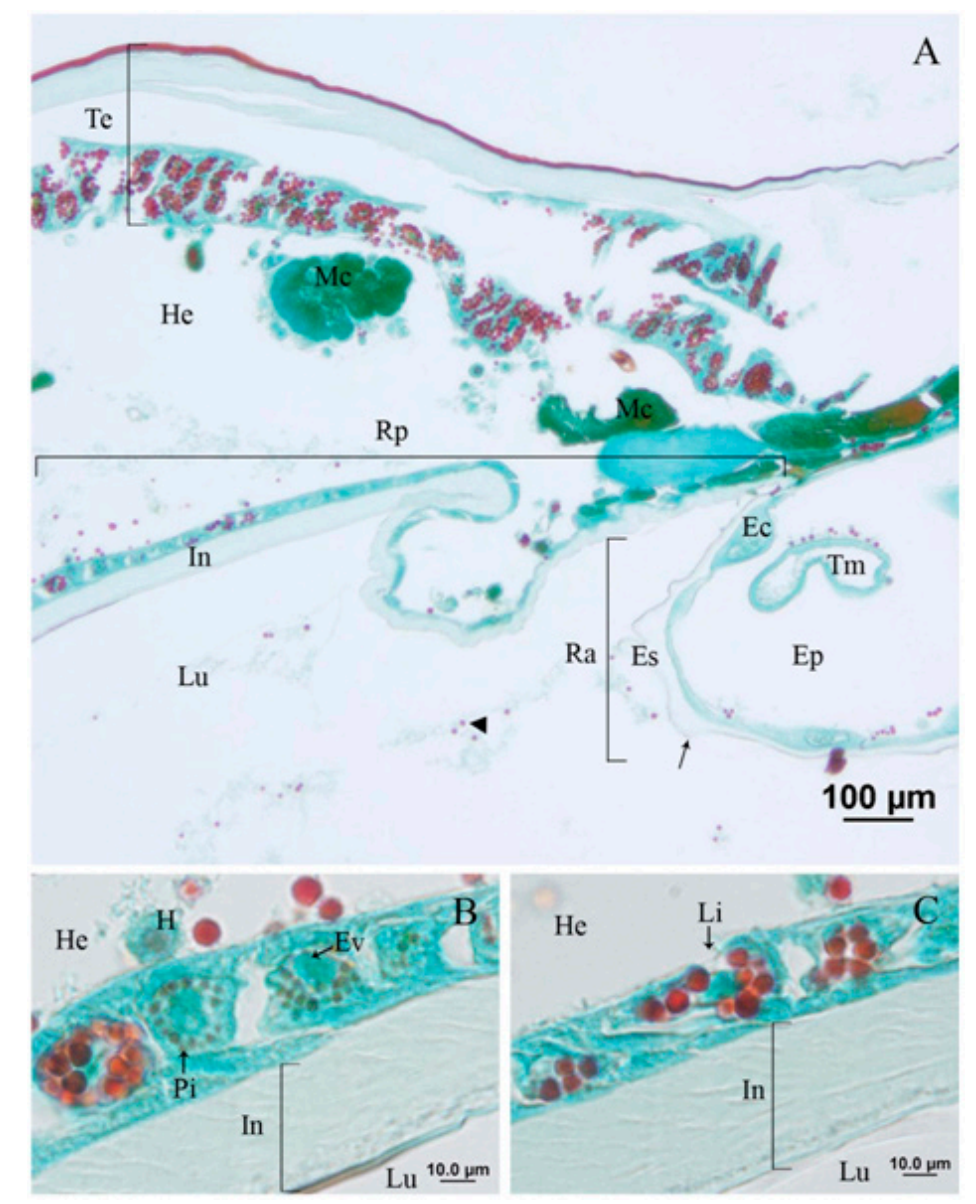

Figure 1. Photomicrographs of the rectum fifth instar Bombyx mori larvae inoculated with BmMNPV on the fifth dpi, longtitudinal cut, modified Azan staining. A. Anterior rectum (Ra), where the following are displayed: cryptonephric rectal epithelium (Ec), the subcuticular space (Es) resulting from detachment of the intima (black arrow), the perinephric space (Ep), and Malpighian tubule (Tm); the posterior rectum (Rp), where the intima (In) can be seen to be adhered to the epithelium. Tegument (Te), circular muscle (Mc), and lumen with polyhedra (arrowhead). B. C. Detail of the posterior region of the rectal epithelium showing cytopathology. B. Nuclei with hypertrophic virogenic stroma (Ev), greenish immature viral polyhedra ( $\mathrm{Pi}$ ), and mature polyhedra (in red), also present in the hemocoel, hemocyte (H). C. Lysis of the epithelial cells (Li). Rectal lumen ( $\mathrm{Lu})$, hemocoel (He), and intima (In). 
Immature and mature viral polyhedra were identified in the nuclei of infected cells (Figures 1A, B, C, and 2A). The immature polyhedra were smaller with a greenish color and did not have a defined geometric shape (Figure 1B), while the mature ones were larger, red in color and with a characteristic geometric shape (Figure 1B and C). The development of polyhedra was discussed by Brancalhão et al. (2009), who analyzed the silk gland of B. mori. Torquato et al. (2006b) characterized the geometric shape of the geographic isolate BmMNPV as a truncated octahedron, but they also mentioned the occurrence of different viral formats.

The infectious cycle of BmMNPV resulted in cell lysis and the release of these viral polyhedrons into the extracellular medium (Figures 1A, B, and C, 2B and C), like reported by Ribeiro et al. (2009a). Lysis results from the action of p10, a multifunctional protein whose association with tubulin filaments promotes the disruption of the nucleus and cell (Rohrmann, 2011; Liang et al., 2013).

The anal canal of the larvae was continuous with the integument, and the soft tissue cells showed typical signs of BmMNPV infection on the fifth dpi (Figure 2A), as observed by Brancalhão and Ribeiro (2003). These authors described the fragility of the integument, with disarray in the procuticle causing its rupture, which leads to the elimination of a milky fluid, a characteristic sign of infection by nucleopolyhedroviruses. This was also observed in the present study.

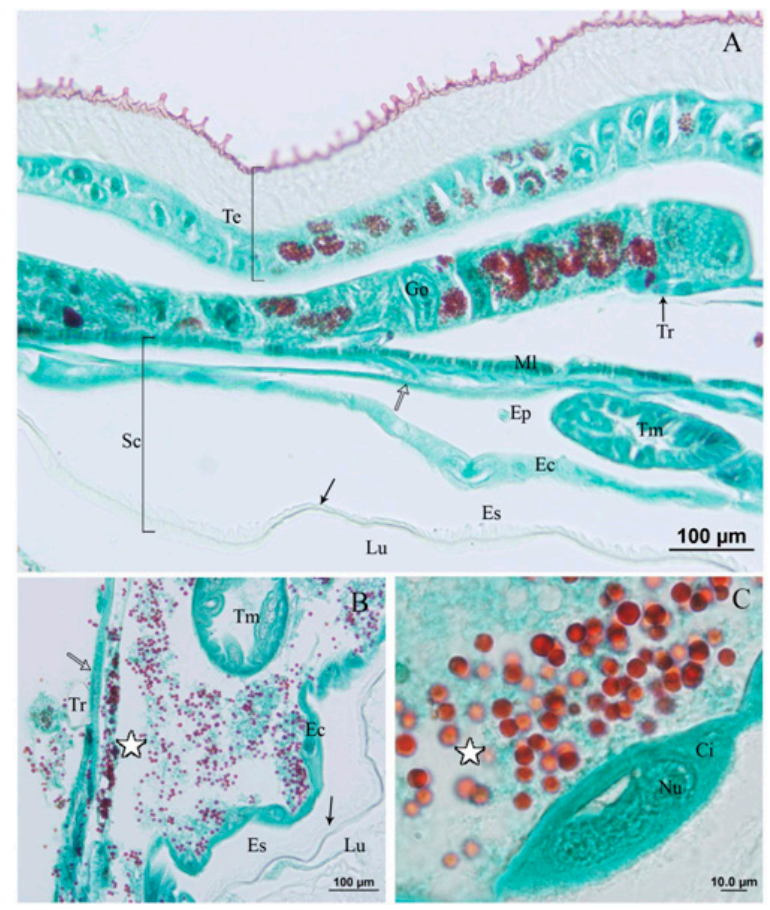

Figure 2. Photomicrographs of the anterior rectum of Bombyx mori larvae inoculated with BmMNPV at fifth dpi (A) and seventh dpi (B and C), longtitudinal cut, modified Azan staining. Note that the cryptonephric rectal epithelium (Ec) shows no signs of infection, best viewed in detail in $\mathbf{C}$, which shows the nucleus $(\mathrm{Nu})$ and cytoplasm $(\mathrm{Ci})$ of the cell. A. Infected cells in the epithelium of the tegument (Te) and fatty body (Go), where the viral polyhedra can be seen (in red), detached intima (black arrow), subcuticular space (Es), perinephric membrane (hollow arrow), perinephric space (Ep), and cryptonephric system (Sc). Trachea (Tr), longitudinal muscle (Ml) and Malpighian tubule (Tm). B. Many polyhedra in the perinephric space (star), which are also visible in $\mathbf{C}$. 
According to Adams and McClintock (1991), the absence of infection in the cryptonephric rectal epithelium cells (Figure 2A, B, and C) can be a result of a differential expression of viral genes inserted into the genome of the host cell, since the NPV shows asynchronous reproduction. Other authors (Ribeiro et al., 2009b; Qin et al., 2012) have highlighted the possibility of resistance in cells of B. mori whose genetic basis is not clarified. Rohrmann (2011) noted that resistant cells of $B$. mori express the protein beta- $\mathrm{N}$-acetylglucosaminidase-2, which affects the binding of GP64, a viral fusion protein linked to the infective capacity of the NPVs.

However, even though infection was not observed in the anterior region, tissue disorganization was apparent, resulting mainly from cytolysis of the tracheas, a known target for BmMNPV (Dourado et al., 2011) and which was present in the perinephric space. The viral polyhedra accumulated in the cryptonephric system from the seventh dpi (Figure 2B and C). According to Azuma et al. (2012), water transport is carried out by basal and apical aquaporins that are present in epithelial cryptonephric rectal cells and Malpighian tubules, whose guidance establishes a concentration gradient that directs the flow of water between the lumen of the rectum, the perinephric space, and the hemolymph. Thus, the presence of BmMNPV in the perinephric space certainly affects the ion gradient, required for the recycling of water to occur, and therefore, the fecal pellets had a hydrated pasty appearance (not shown).

Thus, the infection of the anal canal, in addition to other known targets, as well as the accumulation of polyhedra in the perinephric space affects the physiology of the rectum in such a way as to compromise the metabolic balance of the insect, with consequences on the production of silk. Additionally, the release of the viral polyhedra into the environment, especially in the anus and tegument, enable the horizontal transmission of the disease. According to Porto et al. (2005) and Potrich et al. (2007), sericulture producers should exercise due care in handling $B$. mori larvae, and when the typical signs of nuclear polyhedrosis are identified, the larvae should be eliminated and the whole breeding environment, including utensils, must be disinfected.

\section{ACKNOWLEDGMENTS}

The authors thank the sericulture company BRATAC for providing the larvae and also UNIOESTE and the MA Program in Biosciences and Health for the opportunity to conduct this research.

\section{REFERENCES}

Adams JR and McClintock JT (1991). Baculoviridae. Nuclear Polyhedrosis Viruses. Part 1. Nuclear Polyhedrosis Viruses of Insects. In: Atlas of Invertebrate Viruses (Adams JR and Bonami JR, eds.). CRC Press, Florida, 89-180.

Azuma M, Nagae T, Maruyama M, Kataoka N, et al. (2012). Two water-specific aquaporins at the apical and basal plasma membranes of insect epithelia: molecular basis for water recycling through the cryptonephric rectal complex of lepidopteran larvae. J. Insect Physiol. 58: 523-533.

Beçak W and Paulete J (1976). Técnicas de Citologia e Histologia. Livros Técnicos e Científicos, Rio de Janeiro.

Brancalhão RMC (2002). Vírus entomopatogênicos no bicho-da-seda: taxonomia e citopatologia causada por nucleopolyhedrovirus em células de Bombyx mori. Biotecnologia 24: 54-58.

Brancalhão RMC and Ribeiro LFC (2003). Citopatologia da infecção causada por BmNPV no tegumento de Bombyx mori L., 1758 (Lepidoptera: Bombycidae). Arq. Ciênc. Vet. Zool. 6: 15-20.

Brancalhão RMC, Souza VBV and Soares MAM (2002). Infecção causada por nucleopolyhedrovirus nas células gordurosas de Bombyx mori L., 1758 (Lepidoptera: Bombycidae). Arq. Inst. Biol. 69: 57-63.

Brancalhão RM, Torquato EF and Fernandez MA (2009). Cytopathology of Bombyx mori (Lepidoptera: Bombycidae) silk gland caused by multiple nucleopolyhedrovirus. Genet. Mol. Res. 8: 162-172. 
Chapman RF (1998). The Insect Structure and Function. 4th edn. Amer. Elsev, New York.

Dourado LA, Ribeiro LF, Brancalhao RM, Tavares J, et al. (2011). Silkworm salivary glands are not susceptible to Bombyx mori nuclear polyhedrosis virus. Genet. Mol. Res. 10: 335-339.

Fan Q, Li S, Wang L, Zhang B, et al. (2007). The genome sequence of the multinucleocapsid nucleopolyhedrovirus of the Chinese oak silkworm Antheraea pernyi. Virology 366: 304-315.

Hamm JJ (1966). A modified azan staining technique for inclusion body viruses. J. Invertebr. Pathol. 8: 125-126.

Henson H (1937). The structure and post-embryonic development of Vanessa urticae (Lepidoptera). Quart. J. Micr. Sci. 74: $321-360$

Hong HK, Woo SD, Choi JY, Lee HK, et al. (2000). Characterization of four isolates of Bombyx mori nucleopolyhedrovirus. Arch. Virol. 145: 2351-2361.

Hu Z, Luijckx T, van Dinten LC, van Oers MM, et al. (1999). Specificity of polyhedrin in the generation of baculovirus occlusion bodies. J. Gen. Virol. 80 (Pt 4): 1045-1053.

Ikuno AA, Margatho LFF, Harakava R and Akamatsu MA (2004). Direct application of the new PCR protocol for evaluation and monitoring of Bombyx mori infection by nucleopolyhedrovirus. Arq. Inst. Biol. 71: 309-315.

Jehle JA, Blissard GW, Bonning BC, Cory JS, et al. (2006). On the classification and nomenclature of baculoviruses: a proposal for revision. Arch. Virol. 151: 1257-1266.

Junqueira LC and Junqueria LMMS (1983). Técnicas Básicas de Citologia e Histologia. Livraria e Editora Santos, São Paulo.

Liang X, Lu ZL, Wei BX, Feng JL, et al. (2013). Phylogenetic analysis of Bombyx mori nucleopolyhedrovirus polyhedrin and p10 genes in wild isolates from Guangxi Zhuang Autonomous Region, China. Virus Genes 46: 140-151

MacGown MW and Sikorowski PP (1982). Anatomy of the digestive system of Heliothis zea (Lepidoptera; Noctuidae) Larvae. Mississippi. Mafes. 905.

Pereira EP, Conte H, Ribeiro LF, Zanatta DB, et al. (2008). Cytopathological process by multiple nucleopolyhedrovirus in the testis of Bombyx mori L., 1758 (Lepidoptera: Bombycidae). J. Invertebr. Pathol. 99: 1-7.

Porto AJ, Okamoto F, Ikuno AA and Ferreira VCA (2005). Avaliação biológica e produtiva do bicho-da-seda (Bombyx mori L.) alimentado com folhas de amoreira pulverizadas com extrato de Mirabilis jalapa. Arq. Inst. Biol. 72: 445453.

Potrich M, Alves LFA, Brancalhão RC and Dalcin G (2007). Entomopatógenos associados a lagartas de Bombyx mori L. (Lepidoptera: Bombycidae) no Estado do Paraná. Arq. Inst. Biol. 74: 363-367.

Qin L, Xia H, Shi H, Zhou Y, et al. (2012). Comparative proteomic analysis reveals that caspase-1 and serine protease may be involved in silkworm resistance to Bombyx mori nuclear polyhedrosis virus. J. Proteomics 75: 3630-3638.

Ramsay JA (1976). The rectal complex in the larvae of lepidoptera. Philos. Trans. R. Soc. Lond. B Biol. Sci. 274: 203-226.

Reinecke JP, Cook BJ and Adams TS (1973). Larval hindgut of Manduca sexta (L.) (Lepidoptera: Sphingidae). Int. J. Insect Morphol. Embryol. 2: 277-278.

Ribeiro LF, Brancalhao RM, Torquato EF and Fernandez MA (2009a). Susceptibility of the Bombyx mori cardia cells to nucleopolyhedrovirus, multiple subgroup, BmMNPV. J. Invertebr. Pathol. 100: 195-198.

Ribeiro LF, Zanatta DB, Bravo JP, Brancalhao RM, et al. (2009b). Molecular markers in commercial Bombyx mori (Lepidoptera: Bombycidae) hybrids susceptible to multiple nucleopolyhedrovirus. Genet. Mol. Res. 8: 144-153.

Rohrmann GF (2011). Baculovirus Molecular Biology. Bethesda (MD): National Library of Medicine (US), National Center for Biotechnology Information. Available at [http://www.ncbi.nlm.nih.gov/books/NBK49500/]. Accessed December 7, 2012.

Srivastava BP (1959). Morphology of the alimentary canal of the larva of Leucinodes orbonalis Guen. (Lepidoptera, Pyraustidae). Agricult. Inst. 25: 188-200.

Torquato EF, Neto MH and Brancalhao RM (2006a). Nucleopolyhedrovirus infected central nervous system cells of Bombyx mori (L.) (Lepidoptera: Bombycidae). Neotrop. Entomol. 35: 70-74.

Torquato EF, de Miranda Neto MH, Brancalhao RM and Franco VS (2006b). Nucleopolyhedrovirus: scanning electron microscopy technique. Neotrop. Entomol. 35: 787-790. 